\title{
Perspectives on Archival Resources: The 1985 Census of Archival Institutions
}

\author{
PAUL CONWAY
}

\begin{abstract}
This article is a report on the first comprehensive survey of the resources, responsibilities, and activities of archival repositories in the United States. After placing the study in the context of past surveys of archivists and institutions, and describing its design, the article characterizes the findings on five basic resources common to all archives-money, staff, holdings, facilities, and users. Summary tables permit comparisons of the responses to key survey questions across eight types of archivesfederal, state, local, academic, religious, business, special subject, and museum. The author concludes with recommendations for improving future studies.
\end{abstract}

\footnotetext{
About the author: Paul Conway has been an archivist at the Gerald R. Ford Library in Ann Arbor for ten years. He has an M.A. in history from the University of Michigan and is currently a fulltime doctoral student at the School of Information and Library Studies, University of Michigan. While serving on SAA's Task Force on Institutional Evaluation, he helped design and carry out the 1985 census. The author would like to thank Mary Jo Pugh for her support, encouragement, and substantive comments. The opinions expressed are those of the author and do not necessarily represent the views of the Society of American Archivists.
} 
FOR NEARLY FORTY YEARS, archivists have plotted the vitality of their profession in a series of surveys and studies. From early efforts to mine the Society of American Archivists' membership directory to recent detailed salary surveys, archivists have moved toward a broad understanding of the country's archival resources, responsibilities, and activities. The 1985 census of archival institutions is the most recent and most ambitious effort to date. The purpose of the study was to build a base of statistical information on all types of archival repositories in the United States. Members of SAA's Task Force on Institutional Evaluation, who designed and carried out the study, viewed it as an important step in measuring and comparing archival programs in meaningful ways. Despite the flaws that are an inevitable part of any study of this complexity, the 1985 census generated a wealth of information that will permit archivists to place their programs in the context of broad national patterns.

By collecting a comprehensive range of information from all types of archival repositories rather than from individual archivists, the 1985 study differed from previous efforts. For his SAA presidential address in 1956, Ernst Posner summarized responses to questionnaires returned for the Society's first membership directory. He limited his report to gender differences and the educational background of archivists. ${ }^{1}$ In 1965 Philip
Mason queried a diverse group of archives and historical agencies, well beyond the Society's membership rolls; yet his study focused primarily on professional salaries and financial conditions. ${ }^{2}$ For their comprehensive SAA membership survey in 1970, Frank Evans and Robert Warner highlighted the qualifications, responsibilities, and compensation of archivists, rather than developing a profile of institutions. ${ }^{3}$ Mabel Deutrich's 1974 study of salary differences between male and female archivists and her broader study in 1979 continued the focus on individual training and rewards for archival work. ${ }^{4}$ David Bearman's 1982 survey was the most recent attempt to profile the entire archival profession, but-like its predecessors-the study was limited primarily to identifying the most important factors contributing to differences in archival salaries. ${ }^{5}$

Nicholas Burckel and Frank Cook's comprehensive survey in 1980 of college and university archives set a standard of thoroughness for institutional studies. ${ }^{6}$ Continuing a thirty-year tradition in the archives of higher education, their study sought to identify patterns in staffing, budgets, holdings, services, and facilities at the repository level. Burckel and Cook benefited from the timely publication of a complete directory of colleges and universities and so were able to select a random sample and achieve a higher response rate than a typical mail survey.

'Ernst Posner, "What, Then, Is the American Archivist, This New Man?" American Archivist 20 (January 1957): 3-11.

${ }^{2}$ Philip P. Mason, “Economic Status of the Archival Profession, 1965-66," American Archivist 30 (January 1967): 105-22.

${ }^{3}$ Frank B. Evans and Robert M. Warner, "American Archivists and Their Society: A Composite View," American Archivist 34 (April 1971): 157-72.

${ }^{4}$ Mabel E. Deutrich, "Women in Archives: A Summary Report of the Committee on the Status of Women in the Archival Profession," American Archivist 38 (January 1975): 43-46; Mabel Deutrich and Ben DeWhitt, "Survey of the Archival Profession-1979," American Archivist 43 (Fall 1980): 527-35.

'David Bearman, “1982 Survey of the Archival Profession,"' American Archivist 46 (Spring 1983): 233-41.

'Nicholas C. Burckel and J. Frank Cook, "A Profile of College and University Archives in the United States," American Archivist 45 (Fall 1982): 410-28. 
Response to the Burckel and Cook study was 88 percent, compared to 40 percent for most of earlier studies.

\section{Survey Design and Procedure}

The sixteen-page questionnaire of the 1985 census was more complex than past archival survey efforts. The nine parts roughly paralleled SAA's "Principles of Institutional Evaluation," and included fifty-two questions on resources (finances, staff, holdings, facilities), responsibilities (administration, outreach), and activities over the archival life cycle of records (acquisition, description and processing, reference). ${ }^{7}$ While three pretests and professional consultation smoothed the phrasing, structure, and technical format, some bugs remained in the final questionnaire. In retrospect, especially troublesome areas were inappropriate response categories, requests for complex but marginally useful information, and inadequate definitions of terms. Indeed, the entire project was a lesson in how many ways simple phrases can be interpreted.

SAA mailed 1,253 questionnaires to a master mailing list compiled from its individual and institutional membership rolls in the United States, purged for duplicate repositories. No master list or current directory of archival repositories exists. After careful consideration, the Task Force decided against using the much larger, and severely outdated National Historical Publications and Records Commission list of repositories because of technical limitations on sorting and selection. Budgetary constraints prohibited the expansion of SAA's list to include repositories outside its immediate network. Given these limits, the study is not necessarily representative of all American archives, but rather is a view of the core group of repositories that are associated in some way with SAA. Much work should be done to build a more complete and flexible list of repositories for future surveys.

Five hundred forty-nine repositories returned a questionnaire, including the National Archives in Washington, D.C. The 44 percent response rate compared favorably with David Bearman's 1982 survey, but fell far short of responses to the Burckel and Cook study. Many respondents commented at length about their programs and the problems they encountered in completing the questionnaire. These comments are an important aid for interpreting the statistics generated in the data analysis.

The response rate could have been improved significantly by two simple actions. First, a follow-up mailing or mailings would have dislodged a number of questionnaires from the bottom of inboxes. A recent Library of Congress user survey required five follow-up mailings to achieve a response rate exceeding 90 percent. ${ }^{8}$ Broader promotion of the study also would have been helpful. A brief feature in Catholic Weekly, for example, increased the participation by religious archives relative to other groups. Any future commitments to profession-wide surveys should carry an equally strong commitment to adequate follow-up and publicity. ${ }^{9}$

\footnotetext{
${ }^{7} S A A$ Newsletter, July 1986 , pp. 7-10.

${ }^{8}$ Personal communication from Daniel Melnick, Library of Congress.

${ }^{9}$ Data from each questionnaire was entered into the University of Michigan main frame computer by Information Transfer Systems, Inc. of Ann Arbor. All consistency checking, cleaning, modification, and transformation of the data set was carried out by the author, as was all data analysis and technical documentation. The data set now resides on nine-track tape and is readable by main frame computers and IBM personal computers equipped with hard disk storage and statistical analysis software. Statistical analysis on the University of Michigan's mainframe computer was carried out with OSIRIS.IV software developed and marketed by the Institute for Social Research, Ann Arbor, Michigan.
} 
If the response rate is a potential problem in interpreting the findings, the existence of missing data (information requested but not provided) is a potential opportunity disguised as a problem. With the exception of the first question on repository type, no part of the questionnaire was completed by everyone. Sections of a survey were typically left blank because a repository did not have the information available, did not compile it in the form requested, or did not choose to report it. Even though the questionnaire urged respondents to note whether the question was inapplicable or the data were unavailable, few provided this information. Particularly incomplete were sections on finances, reference, and descriptive practices. Relatively strong sections included staff, facilities, and holdings.

The strengths and weaknesses of repository reporting capabilities were portrayed in patterns of missing data. A basic purpose of the study was to identify units of information that all repositories should try to collect on a regular basis. The questionnaire drew on the recommendations of the SAA Task Force on Standard Reporting Practices concerning the definition of terms and units of measure. ${ }^{10}$ In this context, the responses were a test of the similarity of reporting procedures. Future studies will provide a means of measuring progress toward the goal of complete and comparable reporting.

Reported below are the major findings from portions of the survey on archival resources: money, staff, holdings, facilities, and users. The statistics and examples that follow elaborate on an earlier summary report by showing how archival resources vary among eight types of repositories. ${ }^{11}$ All analyses exclude data from National Archives facilities in the Washington, D.C. area. Readers should note that not all statistics in the accompanying tables are described in the text, and some information in the article has been derived from supplementary analyses. Readers should also note that the total number of respondents varies from question to question. Unless explicitly stated, it is not reasonable to expect that the same group of repositories contributed data even to adjacent columns of the same table. The tables were designed only to allow comparisons across types of repositories, not between variables.

For the most important survey questions, the tables include both medians and means. The median, sometimes called the 50th percentile, is the point at which one-half of the respondents are above and one-half are below. It is the most basic way of describing the distribution of responses. The mean, or average, is important for understanding the magnitude and range of responses, since it is sensitive to the value of the responses, not simply the total number. In the following tables, median figures are usually smaller than means because the presence of one or two very large values can easily pull (skew) the mean above the median. The more closely the means and medians approach each other in value, the more evenly the responses are distributed within a particular category.

\section{Types of Repositories}

The most basic finding of the study, if not the most surprising, was that widely diverse institutions call themselves archives. For example, repository monetary resources available ranged from $\$ 100$ to $\$ 12$ million. Archival staffs ranged from 1 to 156 people. Reported holdings totalled as few as 6 linear feet and as many

\footnotetext{
10“'Final Report of Task Force on Standard Reporting Practice," SAA Newsletter, November 1983, pp. 13-16.

"Paul Conway, “Archival Census: First Analysis," SAA Newsletter, March 1986, pp. 10-13.
} 
as 3.1 million feet. Annual research use varied from 2 visitors to over 37,000 visitors. This diversity existed within and across types of repositories.

In the face of such variation, establishing useful groups of repositories was an important preliminary step to understanding the findings. The first question asked respondents to check the best description of their repository and allowed twelve specific categories-federal government, state government, county government, municipal government, public college or university, private college or university, denominational college or university, business, religious, state historical society, local historical society, and special subject. The thirty-nine respondents who checked "other" fell into three groups: museum, non-profit independent organizations, and public libraries.

Fifteen types of archives was far too many for meaningful analysis, necessitating the difficult task of compressing the respondents into a smaller number of categories. In an ideal set of repository types, each institution would fall naturally into one category, and each category would be of similar size and composition, yet distinct in relation to the others. In the real world, assigning a complex institution to a single category meant balancing a number of factors. The complex relationships between the repository and parent, its public, and holdings were weighed before collapsing categories and grouping archives with other, seemingly diverse ones. The type of materials acquired, from the perspective of both subject and origins, involved the sometimes vague distinction between manuscripts and archives. The functions of the repository, including the responsibility of the parent organization to user communities and the role of records management, were also considered. Finally, establishing a typology of archives meant consid- ering the administrative relations between parent and repository, especially the latter's degree of independence.

The nature of the parent, holdings, and public did not, by themselves, necessarily define a repository, although sometimes one of these factors predominated. There was no perfect composition of any grouping, but the process of typecasting was a key to identifying patterns of resources underlying apparent institutional uniqueness.

The eight groups of repositories that emerged from this classification process are listed in Table 1, along with the number of respondents and percentage of the total response. (1) The federal category includes the National Archives in Washington D.C., the presidential libraries, federal records centers, and federal government archival repositories that are not part of NARA. Examples of the latter range from National Park Service sites with small historical records holdings to large records programs in national scientific labs. All are funded by U.S. tax dollars, and most have a strong mandate to serve the government and the public. (2) The state category essentially refers to state-level repositories and includes state government archival programs and state historical societies. Not all state-level programs responded, but a large cross section is represented. (3) The local category is largely a public sector group and includes county and municipal programs and public libraries with public records and private manuscript holdings. (4) The academic category is the largest segment of the study. It groups all respondents (manuscript collections as well as college or university archives) who checked the blocks for public colleges, private colleges, and denominational colleges. (5) Business archives are those that function within a corporate setting, which may be a profit or non-profit organization. This group includes respondents from all hos- 
pital archives. (6) The second largest group of respondents is religious archives, ranging from small parish or convent programs to large diocesan and national administrative programs. (7) Special subject archives are mostly nonprofit, discipline or theme-oriented repositories. The nature of holdings is the primary criteria for inclusion in this group, which includes collections on labor, science, art, literature, music, ethnicity, and local history. While many of these repositories are located on college and university campuses, they identified themselves as special subject archives on the questionnaire. (8) The smallest group, museum archives, emerged as a group from the "other" category and might have been larger had there been a separate category for museums in Question 1. Subsequent surveys should employ these categories to permit respondents to classify themselves appropriately.

\section{Table 1}

\begin{tabular}{|lrr|}
\hline \multicolumn{3}{|c|}{ Type of Repository } \\
Federal & 26 & $5 \%$ \\
State & 60 & $11 \%$ \\
Local & 29 & $5 \%$ \\
Academic & 206 & $38 \%$ \\
Business & 33 & $6 \%$ \\
Religious & 103 & $19 \%$ \\
Special Subject & 73 & $13 \%$ \\
Museum & 19 & $3 \%$ \\
Total & 549 & $100 \%$ \\
\hline
\end{tabular}

\section{Regional Distribution}

Questionnaires from archives in every state in the nation were returned. For purposes of analysis, respondents were grouped into regional categories roughly corresponding to the composition of regional archival organizations. Table 2 identifies the regional distribution of the responses. A close comparison of the regional distribution of respondents with the regional distribution of the full mailing list of the survey shows that responses are slightly weighted in favor of the South and Mountain states, and slightly against the Mid-Atlantic states. In general, regional distribution within repository categories was similar to overall regional patterns. Business archives were slightly better represented in the New England and Mid-Atlantic regions, and federal and state archives were over-represented in the Mountain region.

\section{Table 2}

\begin{tabular}{|lrr|}
\hline \multicolumn{3}{|c|}{ Regional Distribution } \\
New England & 59 & $11 \%$ \\
Mid-Atlantic & 142 & $26 \%$ \\
South & 103 & $19 \%$ \\
Midwest & 154 & $28 \%$ \\
Mountain & 34 & $6 \%$ \\
Pacific & 57 & $10 \%$ \\
Total & 549 & $100 \%$ \\
\hline
\end{tabular}

\section{Age of Repositories}

The questionnaire asked for the founding date of the repository and parent institutions. Almost 90 percent of the archives were established in the twentieth century. Many were formed during the Depression, an outgrowth in part of the WPA records surveys and the founding of the National Archives. The most phenomenal growth has occurred since 1960; almost one-fourth of the archives were established since 1975 . In general, statelevel repositories were oldest. Over 88 percent of the business archives were founded since 1961 . Only four were more than twenty-five years old. Most recent growth has been in local, business, and museum archives.

The study confirmed a long history of neglect of archival records in well established institutions. The average archival repository was established when the parent institution was sixty-eight years old. More than one-half the responding ar- 
chives were founded more than sixty years after the parent, even when those state archives reporting admission to statehood as the parent founding date were excluded. Even more striking, more than 70 percent of those repositories established since 1961 belong to institutions founded before 1900. Special subject, museum, and federal archives had parents in their mid-thirties or early forties, while the parents of new business archives averaged eighty-four years old. The parents of the remaining groups of archives were nearly as tardy, waiting well over seventy years to establish archival programs.

\section{Total Financial Resources}

At least since Ruth Bordin and Robert Warner wrote on archival management, administrators have been warned about the importance of a repository controlling its own budget. ${ }^{12}$ Nevertheless, only 60 percent of respondents claimed to have a separately identifiable budget. Program and salary costs for the remainder were subsumed into the operating budgets of parent institutions. Some types seemed especially less independent; only 42 percent of all academic and 47 percent of all museum archives reported having separate budgets. Separately identifiable budgets definitely affected respondents' ability or willingness to report financial data. Eighty percent of those with separate budgets reported total budgets, compared to 20 percent without separate budgets who would-or coulddivulge even summary information. Public sector archives and special subject repositories were much more likely to report financial figures, while academic and museum archives were much less likely to divulge even summary totals.

Table 3 describes the total resources available and expended by the eight types of repositories. It clearly shows the domination by public sector programs: over 60 percent of all monetary resources are controlled by federal and state repositories. One-half of all repositories have less than \$82,000 available for each year for all programs and services. The National Archives lists its total expenditures in fiscal year 1985 at $\$ 95,138,000$. This figure very nearly equals the $\$ 99$ million reportedly available to the remaining 324 repositories who provided their financial resources. The average state archives budget is larger than any reported by a local, business, or religious archives. The total resources available to state programs equals the resources available to all other archival programs, excluding the federal repositories.

Religious archives have the smallest financial base; 60 percent have total annual budgets under $\$ 25,000$ and almost 90 percent have less than $\$ 100,000$ available. Similarly, 60 percent of the academic archives have under $\$ 100,000$ available. These two types of archives account for 80 percent of the smallest (under $\$ 25,000$ ) and over 60 percent of the medium (under $\$ 100,000$ ) categories. On the other hand, academic and special subject archives are also well represented in the large (over $\$ 100,000$ ) category.

Repository age provides some explanation for these financial resource figures. Newer archives are relatively small and receive less funding. Nearly threequarters of the archives founded since 1975 have less than $\$ 100,000$ available annually for programs and services. The location of repositories, however, has virtually no impact on the distribution of monetary resources. The pattern of small, medium, and large archives is virtually the same in all regions.

\footnotetext{
1966).

${ }^{12}$ Ruth B. Bordin and Robert M. Warner, The Modern Manuscript Library (New York: Scarecrow Press,
} 
Table 3

\begin{tabular}{|c|c|c|c|c|c|}
\hline \multicolumn{6}{|c|}{ Financial Resources } \\
\hline & \begin{tabular}{l}
\multicolumn{1}{c}{ Total } \\
Financial \\
Resources \\
Available \\
(median) \\
\end{tabular} & \begin{tabular}{l}
\multicolumn{1}{c}{ Total } \\
Financial \\
Resources \\
Available \\
(average) \\
\end{tabular} & $\begin{array}{c}\text { Total } \\
\text { Financial } \\
\text { Resources } \\
\text { Spent } \\
\text { (median) } \\
\end{array}$ & $\begin{array}{c}\text { Total } \\
\text { Financial } \\
\text { Resources } \\
\text { Spent } \\
\text { (average) } \\
\end{array}$ & $\begin{array}{l}\text { Percentage } \\
\text { of Funds for } \\
\text { Personnel }\end{array}$ \\
\hline All (548) & $\begin{array}{r}\$ 82,000 \\
(323)\end{array}$ & $\$ 268,920$ & $\begin{array}{r}\$ 75,000 \\
(325)\end{array}$ & $\$ 232,000$ & $\begin{array}{l}75 \% \\
(273)\end{array}$ \\
\hline Federal (25) & $\begin{array}{r}\$ 204,000 \\
(19)\end{array}$ & $\$ 466,900$ & $\begin{array}{r}\$ 204,000 \\
(18)\end{array}$ & $\$ 505,000$ & $\begin{array}{r}85 \% \\
(18)\end{array}$ \\
\hline State $(60)$ & $\begin{array}{r}\$ 416,000 \\
(50)\end{array}$ & $\$ 786,000$ & $\begin{array}{r}\$ 320,000 \\
(51)\end{array}$ & $\$ 637,400$ & $\begin{array}{r}73 \% \\
(50)\end{array}$ \\
\hline Local (29) & $\begin{array}{r}\$ 36,200 \\
(19)\end{array}$ & $\$ 123,000$ & $\begin{array}{r}\$ 35,000 \\
(16)\end{array}$ & $\$ 120,500$ & $\begin{array}{r}70 \% \\
(15)\end{array}$ \\
\hline Academic (206) & $\begin{array}{r}\$ 67,500 \\
(99)\end{array}$ & $\$ 172,000$ & $\begin{array}{r}\$ 66,600 \\
(102)\end{array}$ & $\$ 157,000$ & $\begin{array}{r}79 \% \\
(87)\end{array}$ \\
\hline Business (33) & $\begin{array}{r}\$ 85,000 \\
(19)\end{array}$ & $\$ 134,000$ & $\begin{array}{r}\$ 82,000 \\
(20)\end{array}$ & $\$ 110,700$ & $\begin{array}{r}75 \% \\
(17)\end{array}$ \\
\hline Religious (103) & $\begin{array}{r}\$ 22,000 \\
(62)\end{array}$ & $\$ 50,000$ & $\begin{array}{r}\$ 17,500 \\
(68)\end{array}$ & $\$ 39,700$ & $\begin{array}{r}74 \% \\
(42)\end{array}$ \\
\hline Subject (73) & $\begin{array}{r}\$ 83,000 \\
(46)\end{array}$ & $\$ 210,300$ & $\begin{array}{r}\$ 110,000 \\
(40)\end{array}$ & $\$ 179,300$ & $\begin{array}{r}63 \% \\
(35)\end{array}$ \\
\hline Museum (19) & $\begin{array}{r}\$ 91,000 \\
(9)\end{array}$ & $\$ 444,000$ & $\begin{array}{r}\$ 91,000 \\
(10)\end{array}$ & $\$ 381,400$ & $\begin{array}{r}69 \% \\
(9)\end{array}$ \\
\hline
\end{tabular}

This display of dominance and diversity shows the difficulty of comparing types of repositories simply on the basis of raw monetary resources. Comparing federal and state archives with other groups on this level is well beyond comparing apples and oranges; it is fruitless. Comparison of patterns of resource use may be a more reasonable way to identify similarities among seemingly diverse groups of repositories.

It is widely acknowledged that archival work is labor intensive. The Burckel and Cook survey suggested that salaries and benefits are a very large portion of most academic archives budgets. The 1985 survey strikingly confirmed this suspicion. Column 5 of Table 3 shows that, of all repositories reporting total funds ex- pended annually and total personnel expenses, the average repository spent 75 percent of its funds on personnel. Only 60 percent of these personnel totals included staff benefits. Special subject repositories reported an average 85 percent expended for personnel costs.

\section{Staff and Salaries}

Institutions were queried about the composition, education, experience, and training of its workforce, and the range of salaries paid-high, low, and average. Ninety-six percent of the respondents provided staff totals, while only one-half supplied information on average salaries. Table 4 displays some statistics on staff composition and salaries of the eight repository types. The total staffs of archival repositories ranged from 1 to 156 


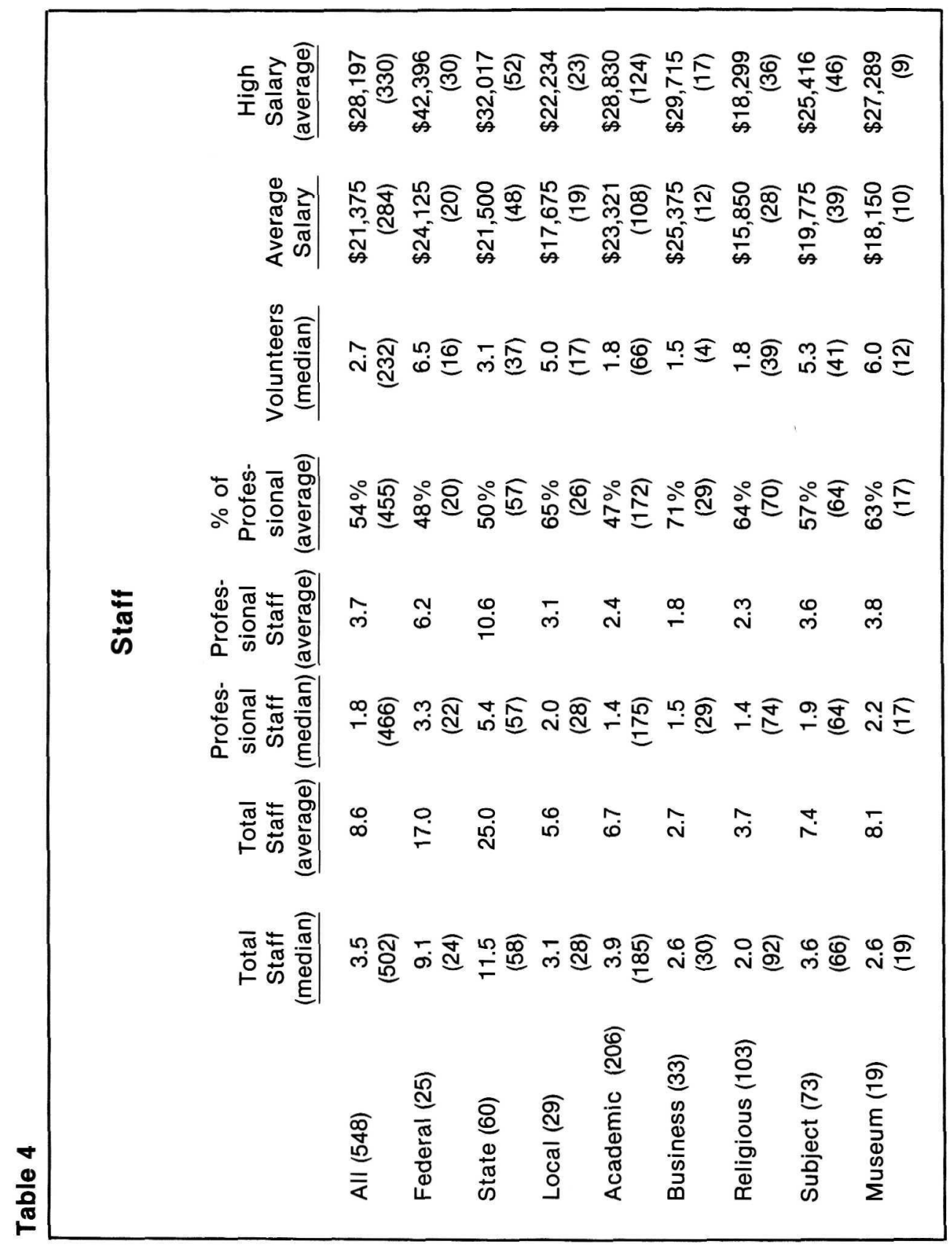


people, excluding the National Archives in Washington. Columns 1 and 2 show that one-half of the repositories reporting staff totals had fewer than 3.5 full-time equivalents (FTE). The range of repository staff size was tremendous: 28 repositories ( 5 percent) reported more than 30 FTEs, while 86 repositories (17 percent) were one-person shops. Similar to the pattern of total monetary resources, federal and state archives typically had the largest staffs, while business, religious, and museum staffs were the smallest. The largest business archives reported a total of only seven employees.

Columns 3 and 4 report the median and average figures for professional staff. Overall, one-half of the repositories reported employing fewer than two FTE professional archivists. Religious, academic, and business archives had the smallest professional staffs as a groupjust one and one-half FTEs, while state repositories typically had over five professional FTEs on the staff.

Column 5 relates total staff to professional staff and reports the overall average percentage of professionals employed by the eight groups from the 455 repositories that reported both total staff and total professional staff FTEs. These figures cast quite a different light on archival administrative structures. Professional archivists comprised an average of 54 percent of the total staff overall. While apparently federal and state repositories had significantly larger total and professional staffs numerically, they had a smaller proportion of professional staff than most other archives. Federal, state and academic archives made the greatest use of non-professional staff, while business and religious archives had the largest proportion of professional staffs.

These figures were probably inflated by the responses from archives whose staff almost without exception consider themselves professional. The survey data cannot evaluate the quality of professional staff. Survey questions on education, training, and experience were not reliable measures because they covered the staff as a whole, were not completed to a significant degree, and were misinterpreted by many. Future studies should look closely at the assessment of staff quality on the repository level. The Burckel and Cook study is a good point of departure.

Many archival repositories seemed to welcome the presence of volunteers on their staffs. Column 6 shows that almost one-half of those repositories that submitted staff totals had 2.7 or more volunteers. Museum, federal, local, and special subject archives reported the largest number of volunteers, while business, academic, and religious archives had the fewest. One special subject repository reported 130 volunteers, while only four business archives had any volunteers at all. Of all repository types, data indicate that academic archives could probably gain the most from increased use of volunteers. Two-thirds of all academic archives reported having no volunteers.

Although identifying the factors affecting compensation for archival work was not a primary focus of the project, data on the salary environment in each repository was gathered for comparative purposes. The average salary nationwide was just under $\$ 21,400$. David Bearman's 1982 study of individual archivists set the average salary at $\$ 21,000 .{ }^{13}$ Even though the studies measured different populations, there were striking similarities in their results. The apparent lack of improvement in archival salaries in the past three years should be viewed with caution, however, since the 1985 figures were probably depressed by the inclusion of clerical support and other non-archival staff in the average figures.

\footnotetext{
${ }^{13}$ Bearman, "1982 Survey of the Archival Profession," 239.
} 
Column 7 in Table 4 lists the average salaries for the eight repository groups. Unlike the figures for total resources and total staff, this column shows a fair amount of homogeneity. For the eight groups of archives, the average salaries were within a $\$ 9,500$ range. Business archivists on the average were paid the most for their work, while religious archivists received the least direct compensation on the average. (Religious totals excluded those who reported working below minimum wage.) The lowest average business salary was greater than the overall averages for local or religious salaries.

Explanation of salary distribution is a complex matter. One of the more intriguing comparative questions is the relation of salaries to staff size. Archivists in larger repositories were not paid more, on the average, than staff in smaller institutions. Average salary figures were distributed in almost equal proportions from the smallest to the largest archives. The pattern was the same for reported lowest salary; archives looked much alike on the low end of the salary range. Not so, however, on the high end-which may be fairly assumed to represent the salary of the director. Over 35 percent (117) reported the highest salary exceeded $\$ 30,000$, the average being $\$ 27,900$. Most significantly, there was a striking correlation between the size of a repository's staff and the director's salary. Seventy-two percent of the archives with more than ten employees had a director paid more than $\$ 30,000$, whereas only 18 percent of the directors of archives with three or fewer employees received such salaries.

\section{Holdings}

The holdings of an archival repository are a third important resource. The questionnaire asked for a seemingly frightening amount of detail on the volume and type of repository holdings, generating 65 variables in eight complex questions. The section's main goal, not entirely met, was to explore the varying composition of archival holdings across types of repositories. While about 70 percent of all repositories provided a figure on the total quantity of holdings in linear or cubic feet, more detailed breakdowns were far less complete. The single most striking conclusion from this avalanche of data was also the most obvious: archives are an incredible mishmash of documents, books, audiovisual items, and all manner of artifacts. Most archives are part repositories of historical documents, part museum, and part library. Any effort to create a homogeneous picture of holdings is a complex and ongoing process requiring careful attention to definition and the context of archival programs within larger institutional settings.

Table 5 is a sampling of facts and statistics from the holdings data. Columns 1 and 2 report the median and average total volume for each type of repository. Archives reported as few as 6 feet of holdings and as many as 137,000 feet, excluding 4 archives with more than 300,000 feet of holdings. Overall, one-half of the 361 repositories that reported a total figure held 2,200 feet of holdings or less. The overall average is a much larger 7,900 feet, due to the presence of a number of very large repositories.

As in previous categories, the federal and state repositories are well endowed with archival resources. Three-quarters of all federal repositories and almost the same portion of state repositories reported more than 5,000 feet of holdings. All other types of repositories were comparatively smaller. Business, museum, and religious archives were the smallest, averaging fewer than 3,000 feet. No business archives reported more than 13,000 feet.

An "Intensity of Care" index, shown in columns 3 and 4 of Table 5 was devel- 
Table 5

\begin{tabular}{|c|c|c|c|c|c|}
\hline \multicolumn{6}{|c|}{ Holdings } \\
\hline & $\begin{array}{c}\text { Total } \\
\text { Volume of } \\
\text { Holdings } \\
\text { (median) } \\
\end{array}$ & $\begin{array}{c}\text { Total } \\
\text { Volume of } \\
\text { Holdings } \\
\text { (average) } \\
\end{array}$ & $\begin{array}{c}\text { Intensity } \\
\text { of Care } \\
\text { (median) }\end{array}$ & $\begin{array}{c}\text { Intensity } \\
\text { of Care } \\
\text { (average) } \\
\end{array}$ & $\begin{array}{l}\text { Cost of } \\
\text { Holdings } \\
\text { (median) }\end{array}$ \\
\hline All (548) & $\begin{array}{l}2,200 \\
(361)\end{array}$ & 7,900 & $\begin{array}{r}403 \\
(350)\end{array}$ & 881 & $\begin{array}{r}\$ 34 \\
(249)\end{array}$ \\
\hline Federal (25) & $\begin{array}{r}14,000 \\
(19)\end{array}$ & 14,500 & $\begin{array}{l}889 \\
(19)\end{array}$ & 1376 & $\begin{array}{l}\$ 37 \\
(16)\end{array}$ \\
\hline State (60) & $\begin{array}{r}9,500 \\
(49)\end{array}$ & 23,600 & $\begin{array}{l}900 \\
(47)\end{array}$ & 1205 & $\begin{array}{l}\$ 31 \\
(44)\end{array}$ \\
\hline Local (29) & $\begin{array}{r}2,200 \\
(22)\end{array}$ & 10,500 & $\begin{array}{l}461 \\
(20)\end{array}$ & 730 & $\begin{array}{r}\$ 141 \\
(12)\end{array}$ \\
\hline Academic (206) & $\begin{array}{l}2,400 \\
(139)\end{array}$ & 5,500 & $\begin{array}{r}485 \\
(136)\end{array}$ & 835 & $\begin{array}{l}\$ 27 \\
(80)\end{array}$ \\
\hline Business (33) & $\begin{array}{r}1,000 \\
(18)\end{array}$ & 2,400 & $\begin{array}{l}400 \\
(18)\end{array}$ & 688 & $\begin{array}{l}\$ 81 \\
(12)\end{array}$ \\
\hline Religious (103) & $\begin{array}{l}650 \\
(52)\end{array}$ & 3,000 & $\begin{array}{l}214 \\
(50)\end{array}$ & 718 & $\begin{array}{l}\$ 29 \\
(43)\end{array}$ \\
\hline Subject (73) & $\begin{array}{r}1,500 \\
(50)\end{array}$ & 4,100 & $\begin{array}{l}377 \\
(48)\end{array}$ & 914 & $\begin{array}{l}\$ 76 \\
(34)\end{array}$ \\
\hline Museum (19) & $\begin{array}{l}800 \\
(12)\end{array}$ & 2,700 & $\begin{array}{l}375 \\
(12)\end{array}$ & 445 & $\begin{array}{r}\$ 75 \\
(8)\end{array}$ \\
\hline
\end{tabular}

oped to measure the relationship between total staff and total holdings for each repository group. The index was computed by dividing the total holdings of each repository by the total repository staff, a crude but effective control for large staffs and large volumes of holdings. The smaller the number, the more intense the care holdings may receive. Overall, onehalf of the 351 repositories included in the index had over 400 feet of holdings for every staff member. Federal and state repositories as a group had more than double this figure, averaging nearly 900 feet per employee. Religious archives had the smallest volume of holdings per staff member (214 feet), while the remaining groups of repositories were within 20 percent of the overall median.

By calculating and charting the Intensity of Care index over time, a repository may assess the development of its archival program. But it should be weighed carefully. An International Council on Archives study has shown that the age of archival materials, the type and format of the items, and even the language of the original item all help to determine the level and nature of care required. ${ }^{14}$

Another measure of repositories and holdings is the relationship between total resources expended and total volume of holdings. This measures the gross cost of acquiring, storing, and servicing archival

\footnotetext{
${ }^{14}$ Harald Jørgensen, “Report on the Cost of Archive Service,” report prepared for a 1973 International Council on Archives roundtable discussion.
} 
materials and is one way to compare the total potential care that holdings may receive. Column 5 shows that one-half of all respondents spent more than $\$ 34$ in 1985 for every foot of holdings stored. This figure included staff costs, applicable facilities charges, supplies, equipment, and other expenses. Medians for federal, state, academic, and religious archives were within 10 percent of the overall \$34 median. Museum, special subject, and business archives spent over twice this amount for each foot of holdings; and local repositories spent $\$ 142$ per foot of holdings-or over four times the national median. While some of the variation may be accounted for in higher salaries, other factors are clearly at play, including inflated facilities charges and relatively small volumes of holdings in repositories with significant "nonarchival" programs.

\section{Facilities}

The archival building is an important resource, but a potentially significant drain on slim program budgets. Seventeen percent of respondents reported paying rent and overhead (e.g., utilities), and in most cases the charges were token, not actual costs. The questionnaire gathered information on the amount of available space and a variety of equipment and services. Table 6 presents the findings on safety and environmental equipment and handicapped access. The discouraging story was confirmed by numerous written comments on the questionnaire. Columns 1 and 2 concern fire detection and suppression equipment. Only three-quarters of all respondents reported having smoke alarms and heat sensors, while less than one-half (44 percent) reported having either sprinkler or gas fire suppression systems. Fire-protected storage space was clearly a problem. One repository reported that its archival storage facility consisted of the long narrow attic of a college dormitory. Only about one-third of local, academic, and religious archives had fire suppression systems.

The data on temperature and humidity controls were only slightly more comforting. Overall, 76 percent of all respondents reported having adequate temperature control. One archivist commented, "If you mean a system that works regularly-forget it!' Museum archives, the newest group of repositories, had the best record for temperature and humidity control, followed closely by federal archives. Only 66 percent of all business archives, one of the newest groups of repositories, reported having adequate temperature control. Column 7 shows that only 60 percent of all repositories reported having handicap access, with federal archives, museum, and special subject repositories leading. ${ }^{15}$

\section{Research Use}

The report of the SAA Committee on Goals and Priorities, Planning for the Archival Profession, refers to use as the ultimate purpose of archival work. From this perspective, the users who visit, write, and telephone for information are a significant archival resource. Yet survey data from institutions, no matter how powerful, cannot address the issues of the quality of research, or the use of archival information beyond the repository. They do give a sense of the magnitude of research use among groups of archives and the associated demands on archival programs. ${ }^{16}$ The questionnaire asked for information on the total number of researchers and daily visits and the total volume of a repository's reference mail and telephone traffic. It asked respon-

\footnotetext{
${ }^{15}$ Brenda Beasley Kepley, “Archives: Accessibility for the Disabled,” American Archivist 46 (Winter 1983): 42-51.

${ }^{16}$ Roy C. Turnbaugh, “Archival Mission and User Studies,” Midwestern Archivist 11, no. 1 (1986): 30.
} 
Table 6

\begin{tabular}{|c|c|c|c|c|c|c|c|}
\hline & & & Facilitie & & & & \\
\hline & $\begin{array}{c}\text { Fire } \\
\text { Detec- } \\
\text { tion }\end{array}$ & $\begin{array}{c}\text { Fire } \\
\text { Suppres- } \\
\text { sion } \\
\end{array}$ & $\begin{array}{c}\text { Tempera- } \\
\text { ture } \\
\text { Control } \\
\end{array}$ & $\begin{array}{c}\text { Humidity } \\
\text { Control }\end{array}$ & $\begin{array}{l}\text { Closed } \\
\text { Stacks }\end{array}$ & $\begin{array}{l}\text { Burglar } \\
\text { Alarms }\end{array}$ & $\begin{array}{c}\text { Handi- } \\
\text { cap } \\
\text { Access }\end{array}$ \\
\hline All (548) & $\begin{array}{l}72 \% \\
(376)\end{array}$ & $\begin{array}{l}44 \% \\
(228)\end{array}$ & $\begin{array}{l}76 \% \\
(394)\end{array}$ & $\begin{array}{l}60 \% \\
(315)\end{array}$ & $\begin{array}{l}78 \% \\
(406)\end{array}$ & $\begin{array}{l}60 \% \\
(311)\end{array}$ & $\begin{array}{l}60 \% \\
(311)\end{array}$ \\
\hline Federal (25) & $\begin{array}{r}92 \% \\
(23)\end{array}$ & $\begin{array}{r}80 \% \\
(20)\end{array}$ & $\begin{array}{r}84 \% \\
(21)\end{array}$ & $\begin{array}{r}80 \% \\
(20)\end{array}$ & $\begin{array}{r}84 \% \\
(21)\end{array}$ & $\begin{array}{r}92 \% \\
(23)\end{array}$ & $\begin{array}{r}92 \% \\
(23)\end{array}$ \\
\hline State $(60)$ & $\begin{array}{r}87 \% \\
(52)\end{array}$ & $\begin{array}{r}50 \% \\
(30)\end{array}$ & $\begin{array}{r}75 \% \\
(45)\end{array}$ & $\begin{array}{r}67 \% \\
(40)\end{array}$ & $\begin{array}{r}93 \% \\
(56)\end{array}$ & $\begin{array}{r}72 \% \\
(43)\end{array}$ & $\begin{array}{r}72 \% \\
(43)\end{array}$ \\
\hline Local (29) & $\begin{array}{r}75 \% \\
(21)\end{array}$ & $\begin{array}{r}32 \% \\
(9)\end{array}$ & $\begin{array}{r}71 \% \\
(20)\end{array}$ & $\begin{array}{r}57 \% \\
(16)\end{array}$ & $\begin{array}{r}68 \% \\
(19)\end{array}$ & $\begin{array}{r}64 \% \\
(18)\end{array}$ & $\begin{array}{r}64 \% \\
(18)\end{array}$ \\
\hline Academic (206) & $\begin{array}{l}68 \% \\
(132)\end{array}$ & $\begin{array}{r}37 \% \\
(73)\end{array}$ & $\begin{array}{l}74 \% \\
(145)\end{array}$ & $\begin{array}{l}50 \% \\
(114)\end{array}$ & $\begin{array}{l}80 \% \\
(155)\end{array}$ & $\begin{array}{l}52 \% \\
(101)\end{array}$ & $\begin{array}{l}52 \% \\
(101)\end{array}$ \\
\hline Business (33) & $\begin{array}{r}72 \% \\
(23)\end{array}$ & $\begin{array}{r}75 \% \\
(24)\end{array}$ & $\begin{array}{r}66 \% \\
(21)\end{array}$ & $\begin{array}{r}59 \% \\
(16)\end{array}$ & $\begin{array}{r}75 \% \\
(24)\end{array}$ & $\begin{array}{r}60 \% \\
(19)\end{array}$ & $\begin{array}{r}60 \% \\
(19)\end{array}$ \\
\hline Religious (103) & $\begin{array}{r}56 \% \\
(54)\end{array}$ & $\begin{array}{r}29 \% \\
(28)\end{array}$ & $\begin{array}{r}74 \% \\
(71)\end{array}$ & $\begin{array}{r}57 \% \\
(57)\end{array}$ & $\begin{array}{r}60 \% \\
(58)\end{array}$ & $\begin{array}{r}38 \% \\
(36)\end{array}$ & $\begin{array}{r}38 \% \\
(36)\end{array}$ \\
\hline Subject (73) & $\begin{array}{r}81 \% \\
(54)\end{array}$ & $\begin{array}{r}54 \% \\
(36)\end{array}$ & $\begin{array}{r}81 \% \\
(54)\end{array}$ & $\begin{array}{r}57 \% \\
(38)\end{array}$ & $\begin{array}{r}85 \% \\
(57)\end{array}$ & $\begin{array}{r}81 \% \\
(54)\end{array}$ & $\begin{array}{r}81 \% \\
(54)\end{array}$ \\
\hline Museum (19) & $\begin{array}{r}90 \% \\
(17)\end{array}$ & $\begin{array}{r}42 \% \\
(8)\end{array}$ & $\begin{array}{r}90 \% \\
(17)\end{array}$ & $\begin{array}{r}74 \% \\
(14)\end{array}$ & $\begin{array}{r}84 \% \\
(16)\end{array}$ & $\begin{array}{r}90 \% \\
(17)\end{array}$ & $\begin{array}{r}90 \% \\
(17)\end{array}$ \\
\hline
\end{tabular}

dents to divide these totals among six categories of researchers: staff of parent institution, genealogists, scholars, students, general public, and "other."

This was the most difficult section of the questionnaire to develop. Archivists have been admonished to refrain from pigeonholing researchers and instead to allow them to describe themelves. ${ }^{17}$ With this warning and archivists' inability to develop a comprehensive typology of users, it was not surprising that respondents made more comments on this section than on any other part of the questionnaire. Essays appeared on the bottom of the page, including this typical one: "We find it irritating of SAA to be using the category 'scholars' as separate from 'genealogists,' 'students,' etc., as if the latter categories were not scholars." More research is needed before archivists can confidently categorize users.

Table 7 presents a few of the statistics from the study's overall reference totals. The most basic conclusion is that archivists do not know who their users are, and moreover, do not seem to be trying to count them. Only two-thirds of all repositories provided even a raw number of research visitors. Of the five resources considered in this article, only total financial data received a lower response. Sensitivity to disclosing financial information is somewhat understandable; total user statistics, however, are not privileged.

\footnotetext{
${ }^{1}$ Elsie T. Freeman, "In the Eye of the Beholder: Archives Administration from the User's Point of View," American Archivist 47 (Spring 1984): 111-23.
} 


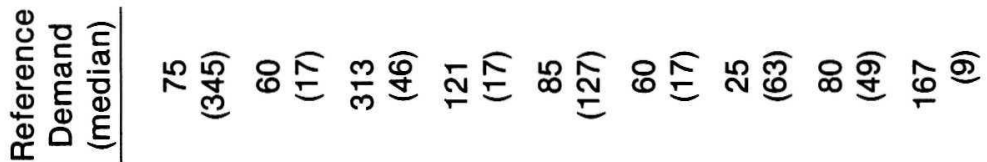

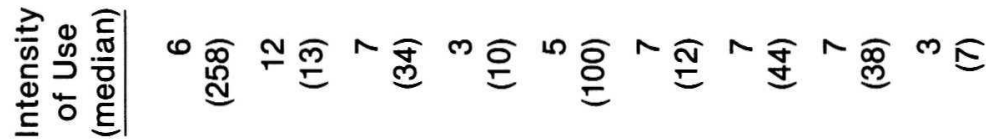

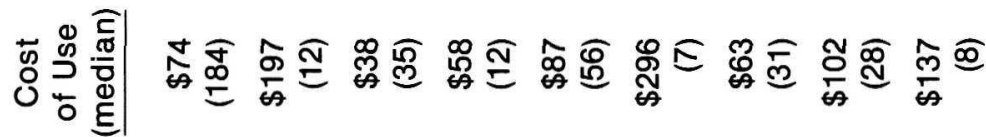

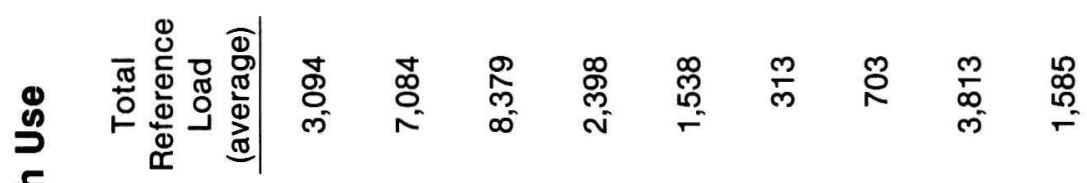

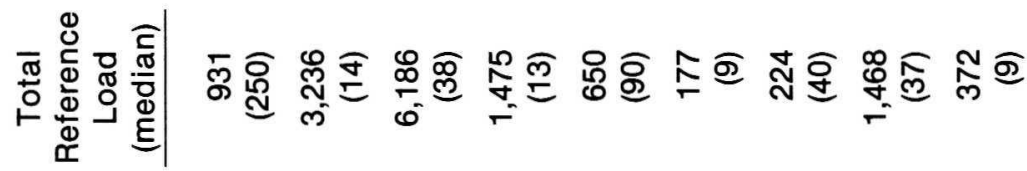

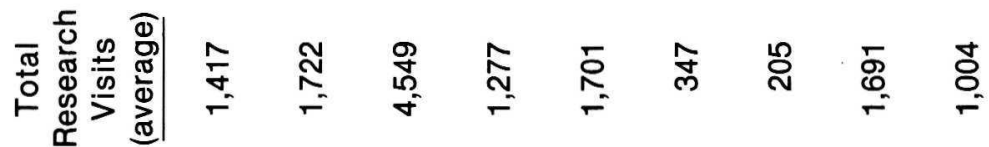

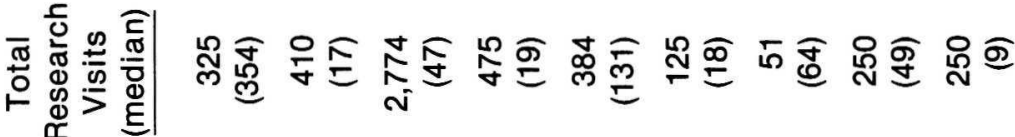


The information on research use from the 354 respondents who provided it is wildly divergent. Some archivists reported as few as 2 and others as many as 37,000 annual research visits. Overall, the annual average number of researchers is just over 1,400 , but one-half of the respondents reported having fewer than 325 people in 1985-barely 1 per day. Columns 1 and 2 show the diversity among repositories. Federal, local, academic, special subject, and museum archives hovered around the middle on both the average and median figures. Business and religious archives had significantly fewer research visitors, and state archives as a group had over three times the national average research use.

Columns 3 and 4 represent the calculated median and average total volume of research: visitors, mail, and telephone requests. It should be noted, however, that the total number of repositories able to provide data on all three activities was only two-thirds of those reporting research visitors. In addition, larger repositories may have had sufficient staff to track correspondence and incoming telephone calls. Together, these factors may account for the inconsistencies between the figures in the first four columns. Clearly, archivists need more accurate and complete record keeping on research use.

The available figures show an even greater disparity among types of archives than the research totals alone. State-level repositories supported the largest volume of total reference by a sizable margin. Federal repositories, dispersed around the country, had a significant amount of reference contacts with non-visitors. Special subject and religious archives also had proportionately higher non-visitor reference than the national median of 931 contacts. The few business archives able to report researcher, mail, and telephone totals had the least demand for reference services of any kind.

If use is the ultimate purpose of archival work, it is instructive to examine whether reference use is commensurate with repository expenditures. Column 5 presents the median figures for the eight repository groups, calculated by dividing a repository's total budgetary expenditures by its total reference load. Again, because financial and user data were generally under-reported, the figures should be used only for rough comparison. Overall, the 184 repositories that reported the necessary figures spent $\$ 74$ in 1985 for every reference contact made. Business (\$296) and federal archives (\$197) spent the greatest amount relative to total direct use, while state (\$38), local (\$58), and religious (\$63) repositories spent the least. Although these figures may not be the fairest and most precise measure, they are a way to equalize the huge disparity among repositories in terms of budgets and total use. They show in gross terms the varying levels of reference demand, and should be useful in future studies.

Two other measures of reference service are the potential demand of research use on archival holdings and on staff resources. The first of these, the "Intensity of Use" index, was compiled by dividing the total volume of holdings by the total number of research visitors. In the aggregate, this index is a way of measuring whether repositories with a greater volume of holdings have correspondingly heavier reference use. The higher the number, the fewer researchers are making use of the holdings overall. The figures in Column 6 suggest that there was relatively little variation among groups of repositories in terms of the demand on holdings. Federal archives have one-half the demand relative to the national median. Local and museum archives on the other hand have about twice the demand. 
Other groups of repositories all hover around the national median of six feet per research visitor.

The final measure, "Reference Demand," captures the relationship between research visitors and staff resources, by dividing the total number of research visitors by the total number of repository staff. Column 7 shows that one-half of all repositories had at least seventy-five researchers visit per year per staff member. Federal, academic, business, and special subject archives all appeared to be under similar pressure in this context. Religious archives, with only twenty-five researchers per year for every staff person, may seem under-staffed at two staff per repository, but they were also under-used. The staffs of state level archives, on the other hand, were almost ten times more pressured by research use than the least used group, followed at some distance by the other public sector group, local archives.

\section{Conclusions}

The above statistics offer a variety of perspectives on the key resources currently available for archival programs and services. But quantitative measures alone cannot and should not describe the quality of archival work. Quality is not measured in the aggregate, but through many careful studies of how individual programs make the best use of available resources. In this regard the averages, and especially the mid-points represented by medians, can be considered as tentative norms-not norms to be enshrined as performance standards, but benchmarks to be exceeded each time a national study is repeated. The data could become points of departure for qualitative assessments presented in case studies-studies that transcend the "This-is-what-we-doin-our-shop-and-isn't-it-neat?"' level to draw out the relationships among resources-money, staff, holdings, facilities, and users.

This static snapshot of archival programs should be transformed into a dynamic portrait of a developing profession. Comprehensive, national-level studies such as this survey need to be repeated regularly-at least every three or four years. To help ensure the success of future efforts both the Society of American Archivists and individual repositories must take some specific actions.

Before the next national survey of archivists or archival institutions for whatever purpose, SAA can do two things to improve the quality of research. First, it can compile a much more comprehensive list of archival repositories in the United States, including the type of repository and other basic information. Second, SAA must analyze the 1985 questionnaire to identify the most useful information that should be regularly collected. The basic format and structure of the questionnaire should be retained; but it should be shortened by removing elements not reasonably ascertained and requests for information that will not contribute to the larger goal of comparing changes in types of repository programs.

In the next few years, individual repositories can also take action to improve future national studies. First, they should compare the averages and medians in this report and future reports against their specific repository activity. They can use the data as a point of departure for detailed self-studies and realistic comparisons with similar types of repositories. Second, all repositories should begin compiling statistics in a form compatible with the survey questionnaire.

Every archival repository is unique. Archivists can take pride and find strength in the diversity of creative approaches to planning, administration, and reporting. Individually successful 
programs contribute to the slowly developing archival profession. The 1985 census of archival institutions has shown that patterns of performance exist. Identifying patterns of success is as important to the profession as recognizing individual performance. Repeated national studies of archival repositories are useful tools for discovering similarities among repositories and recognizing areas where differences are powerful and should be respected. By clarifying existing patterns and showing how they are evolving, present and future national studies can identify the common ground-the highest common denominator-that can serve as a foundation for widely accepted standards for archival programs. 